\title{
FGFR3 NP_000133.1:p.G380R
}

National Cancer Institute

\section{Source}

National Cancer Institute. FGFR3 NP 000133.1:p.G380R. NCI Thesaurus. Code C128907.

A change in the amino acid residue at position 380 in the fibroblast growth factor receptor 3 protein where glycine has been replaced by arginine. 